\title{
MOLECULAR BIOLOGICAL STUDIES ON TRANSCRIPTION FACTOR ESTROGEN-RECEPTOR IN BREAST CANCER TREATED WITH LECTIN Mohamed El-Shal $^{1}$; Ibrahim El-Sayed ${ }^{2}$; Wael S. Abdel-Mageed ${ }^{3}$; Mahmoud E. Gadalla ${ }^{4}$ and Norhan M. Eid ${ }^{1}$ \\ 1. Molecular Biology Department, Genetic Engineering and Biotechnology Research Institute, University of Sadat City, Egypt. \\ 2. Chemistry Department, Faculty of Science, Kafrelsheikh University, Egypt. \\ 3. Genetics Department, Faculty of Agriculture, Beni-Suef University, Egypt. \\ 4. Molecular diagnosis Department, Genetic Engineering and Biotechnology Research Institute, University of Sadat City, Egypt. \\ Corresponding Author: \\ ${ }^{\square}$ Mohamed F. Elshal., Ph.D., Department of Molecular Biology, Genetic Engineering and Biotechnology Research Institute, University of Sadat City, Egypt. \\ Mohamed.Elshal@gebri.usc.edu.eg
}

Key Words: ConA lectin, Tamoxifen, MCF-7 cells, Antitumor

\section{ABSTRACT}

Proteins with legume lectin domains are known to possess a wide range of biological functions. The antitumor effects of Concanavalin-A (ConA) lectin and Tamoxifen (potent antagonist of estrogen and induces apoptosis in MCF-7 cells) on human breast carcinoma cells were investigated in vitro. Human breast carcinoma MCF-7 cells were examined, cell viability, proliferation and cytotoxicity of MCF cells treated with ConA and Tamoxifen using morphological analysis and MTT cytotoxicity assay. The effects of ConA compared to Tamoxifen on the expression of the transcription factor Er $\alpha$ and the expression of antiapoptosis gene (Bcl2) in breast cancer MCF7 cell line were evaluated by RT-PCR. The microscopic examination of cells indicated that ConA induced significant cellular alterations typical of apoptosis cell-death in a comparable manner as Tamoxifen. ConA showed also proliferation inhibition activity, however it was lower than tamoxifen, as indicated by MTT growth inhibition assay. The IC50 of ConA is $7.55 \mu \mathrm{M}$ and of Tamoxifen is $2.75 \mu \mathrm{M}$. The expression of Er $\alpha$ and Bcl2 proteins after treatment with ConA were significantly decreased. In conclusion: ConA induced significant apoptosis and inhibited the proliferation of breast cancer cells that may be through mechanism involve reduction in the expression of ER $\alpha$ and anti-apoptotic gene $\mathrm{BCl}-2$. Finally, our results indicate that ConA exerts anti-tumor actions against human breast carcinoma MCF-7 cells in vitro and confer support for more research to unravel the potentials of using concanavalin-A as complementary treatment of ER+ breast cancer. 


\section{INTRODUCTION:}

Breast cancer is a malignant tumor that starts in the cells of the breast. A malignant tumor is a group of cancer cells that can grow into surrounding tissues or spread to distant areas of the body. The disease occurs almost entirely in women, but men can get it, too (Girish et al. 2014).

Transcription factors typically regulate gene expression by binding cis-acting regulatory elements defined as enhancers and by recruiting coactivators and RNA polymerase II (RNA Pol II) to target genes (Ong and Corces, 2011; Lelli et al. 2012). Enhancers are segments of DNA that are generally a few hundred base pairs in length and are typically occupied by multiple transcription factors (Spitz and Furlong 2012). As for breast cancer, MCF-7 cells represent a very important candidate as they are used ubiquitously in research for estrogen receptor (ER)-positive breast cancer cell experiments and many sub-clones, which have been established, represent different classes of ER-positive tumors with varying nuclear receptor expression levels (Sweeney et al. 2013).

Lectins can inhibit tumor genesis by binding to glycosylated proteins on the membrane of cancer cells. It is well known that glycoconjugates play important roles in many biological processes, including cancer, with malignant cells usually presenting altered glycosylation patterns (Marques et al. 2017). These changes in glycans allow preferential binding of lectin on cancer cells to induce the above effects (Cavada $\boldsymbol{e t}$ al. 2019). Tamoxifen is a drug that has been in worldwide use for the treatment of estrogen receptor (ER)-positive breast cancer for over 30 years; it has been used in both the metastatic and adjuvant settings (Lazzeroni et al. 2012).

This study was aimed to measure cellular metabolic activity as an indicator of cell viability, proliferation and cytotoxicity of MCF cells treated with Concavalin-A (ConA) and compare its cytotoxic effects with the standard breast cancer chemotherapy Tamoxifen (TAM) by MTT cytotoxicity assay. Then, evaluation the effect of ConA lectin or Tamoxifen drug on breast cancer MCF7 cell line by Real Time PCR on the transcription factor protein ER-alpha and the anti-apoptotic $\mathrm{BCl}-2$ gene expression.

\section{Chemicals}

\section{MATERIALS AND METHODS}

RPMI-1640, FBS, trypsin, penicillin, and streptomycin were purchased from Gibco (Invitrogen, Grand Island, NY). 3-(4,5-Dimethyl thiazol-2yl)-2,5-diphenyltetrazolium bromide (MTT), dimethyl sulfoxide (DMSO), were purchased from Sigma-Aldrich (St. Louis, MO). Annexin VFITC and PI double staining kit were purchased from BD (Waltham, MA). Tamoxifen (Sigma, St. Louis, MO) was the standard drugs used as positive control in this study. 


\section{Cell culture}

Breast adenocarcinoma MCF-7 cells were cultured in RPMI1640 media containing $10 \% \mathrm{FBS}, 100 \mathrm{mg} / \mathrm{mL}$ streptomycin, $100 \mathrm{U} / \mathrm{mL}$ penicillin, and $0.03 \%$ L-glutamine and were maintained at $37{ }^{\circ} \mathrm{C}$ with $5 \% \mathrm{CO} 2$ in a humidified atmosphere (Zheng et al. 2014).

\section{MTT Cytotoxicity assay}

The tetrazolium salt 3, (4.5-dimethyl-thiazol- 2-yl)-2, 5-diphenyl tetrazolium bromide (MTT) cytotoxicity assay was used to evaluate antiproliferative capacity of Lectin towards MCF-7 cell line. Briefly, cells were seeded at $2 \times 10^{4}$ cell/well in 96-well tissue culture plates and allowed to attach for $24 \mathrm{hr}$. Cells were then exposed to variable concentrations at 10 , $0.39,1.56,6.25,25$ and $100 \mu \mathrm{M}$ of lectin or Tamoxifen (as positive control) dissolved in the RPMI medium for $24 \mathrm{hr}$. After incubation, plates were centrifuged $(500 \mathrm{~g}, 5 \mathrm{~min}$ ) and the supernatant was removed, followed by an addition of MTT solution $(0.5 \mathrm{mg} / \mathrm{mL}$ in PBS) and incubation for $4 \mathrm{hr}$ at $37{ }^{\circ} \mathrm{C}$ and $5 \% \mathrm{CO} 2$. The medium was discarded, and the cells were then lysed in $10 \% \mathrm{SDS} / \mathrm{HCl} 0.01 \mathrm{~N}$ overnight. Absorbance was measured in a microplate reader at $570 \mathrm{~nm}$. The concentration that inhibits $50 \%$ of cell proliferation (IC50) was determined from plots of cell viability (FaheinaMartins et al. 2011).

\section{Analysis of Apoptosis by Flow Cytometry Assay}

Apoptosis detection was performed by FITC Annexin-V/PI kit (Becton Dickenson, Franklin Lakes, NJ, USA) following the manufacture's protocol. Briefly, cells were harvested in single cell suspension. Cells were incubated with Annexin V-FITC, USA before fixation since any cell membrane disruption can cause nonspecific binding of Annexin V to PS on the inner surface of the cell membrane). The cells were washed and fixed in $2 \%$ formaldehyde before analysis. The cytometer was set for appropriate FSC vs. SSC gates to exclude debris and cell aggregates. Collect annexin V fluorescence at FL-1 and Propidium iodide fluorescence at FL2.

\section{Molecular gene expression analysis}

Analysis of the expression of the anti-apoptosis BCL-2 as well as the expression of the transcription factor ER $\alpha$ gene were done using Real Time Polymerase Chain Reaction (RT-PCR) to identify the molecular effects of con A lectin or tamoxifen on MCF 7 cells. mRNA isolation is carried out using RNeasy extraction kit, up to $1 \times 10^{6}$ cells, depending on the cell line, cells were disrupted in Buffer RLT. Ethanol is then was added to the cell's lysate, creating conditions that promote selective binding of RNA to the RNeasy membrane. The sample was then applied to the RNeasy Mini spin column. RNA was then eluted in RNase-free water. A specific primer used for detection of $\mathrm{Bcl} 2$, and $\mathrm{ER} \alpha$ genes, primers pairs were designed (table 1), and acquired in lyophilized form (BioRad, USA). 
Table 1: the sequences of the specific primers used in the project to amplify regions of $\mathrm{Bcl} 2$, and $\mathrm{ER} \alpha$ genes:

\begin{tabular}{|c|c|c|}
\hline \multirow{2}{*}{ Gene } & \multicolumn{2}{|c|}{ Sequence (5'-3') } \\
\hline \multirow{2}{*}{ Bcl2 } & Forward & AAGCCGGCGACGACTTCT \\
\cline { 2 - 3 } & Reverse & GGTGCCGGTTCAGGTACTCA \\
\hline \multirow{2}{*}{ ERa } & Forward & AATTCTGACAATCGACGCCAG \\
\cline { 2 - 3 } & Reverse & GTGCTTCAACATTCTCCCTCCTC \\
\hline \multirow{2}{*}{ FAPDH } & Forward & GAAGGTGAAGGTCGGAGTCA \\
\cline { 2 - 3 } & Reverse & TTGAGGTCAATGAAGGGGTC \\
\hline
\end{tabular}

PCR amplification was performed in 25uL 2X SYBR Green RTPCR reaction mix, $1.5 \mathrm{uL}$ of each primer $(10 \mathrm{uM}), 10 \mathrm{uL}$ of RNA template (1pg to 100ng total RNA), $11 \mathrm{uL}$ of Nuclease-free $\mathrm{H} 2 \mathrm{O}$ and $1 \mathrm{uL}$ of iScriptT reverse trancriptase for one- step RT-PCR (total volume 50uL). The cycling conditions for detection of ER $\alpha$ and $\mathrm{Bcl} 2$ were done by Rotorgene Q RT- PCR system, Germany.

\section{Morphological changes}

\section{RESULTS}

MCF-7 cells were the epithelial-like and grow in monolayers. When grown in vitro, the cell line was capable of forming domes before plating (75\% cells). MCF7 cells were grown, propagated and proliferated forming chains after plating (85\% cells) for $24 \mathrm{~h}$ incubation. Figure 1 demonstrates the morphological changes of cells after treatment with ConA or Tamoxifen drug, which indicated that either treatments resulted in remarkable morphological changes typical of apoptosis and major proliferation inhibition, however TAM showed more prilferation inhibitory activity on cells than ConA.

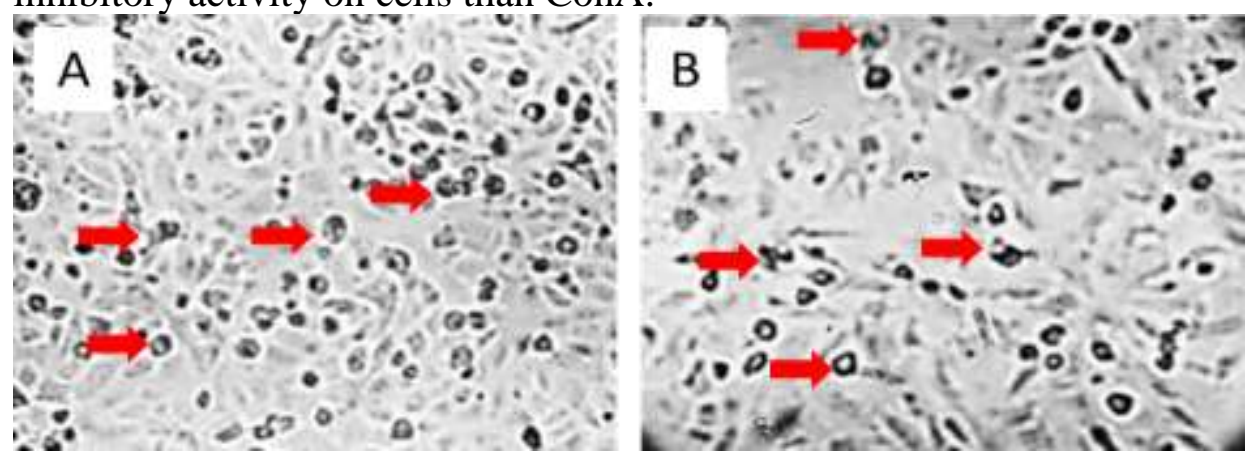

Figure 1: Microscopic examination of MCF-7 treated with lectin (A) and tamoxifen (B). Red arrows refer to apoptotic cancer cells.

\section{Cytotoxic effect of ConA Lectin and Tamoxifen on MCF7 cells}

Cells were incubated with different concentrations of ConA and Tamoxifen $(0.39,1.56,6.25,25,100 \mathrm{uM})$ as shown in Figure 2. The MTT cytotoxicity results indicated that ConA has a less potent growth 
inhibitory activity toward MCF-7 cells than Tamoxifen. The IC50 is the concentration of an inhibitor where the response is reduced by half ConA is $7 \mu \mathrm{M}$, and in Tamoxifen is $3 \mu \mathrm{M}$ (figure 2).

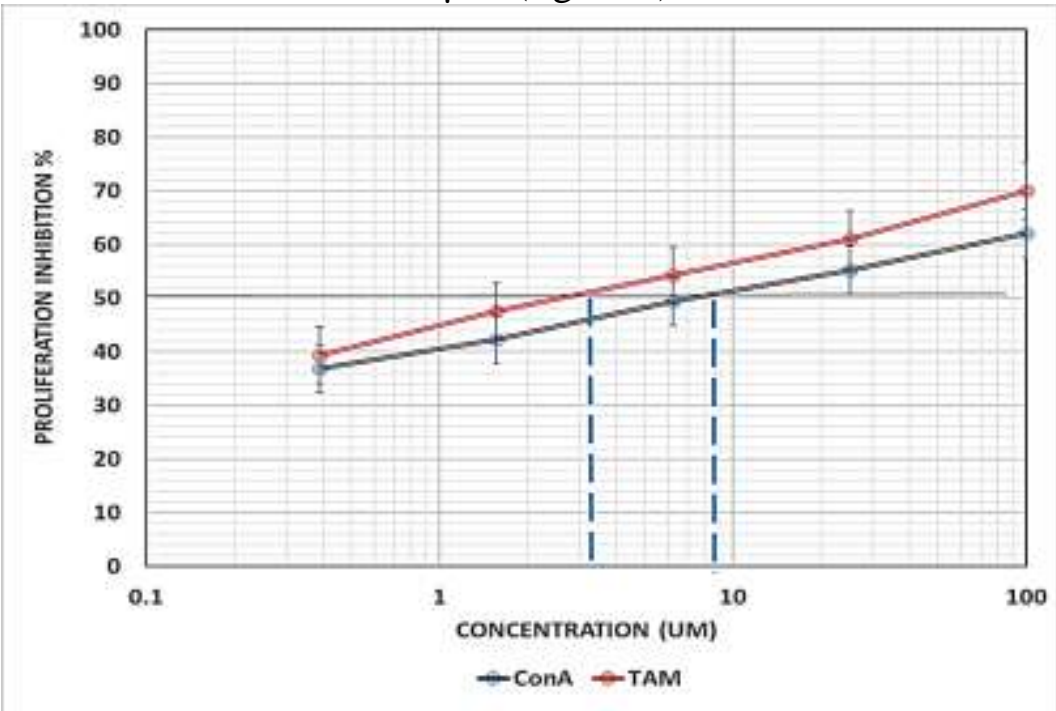

Figure 2: Inhibitory rate and calculation of IC50 of ConA and Tamoxifen. ConA IC $50=7 \mu \mathrm{M}$, TAM IC $50=3 \mu \mathrm{M}$. Data representative of mean of three independent experiments.

\section{Genes Expressions}

ER alpha was down regulated that inhibited the growth MCF7 Cells treated with conA and Tamoxifen (figure 3A). The anti-apoptosis gene $\mathrm{BCl}-2$ expression was found decreased after the addition of ConA and Tamoxifen drug (figure 3B).

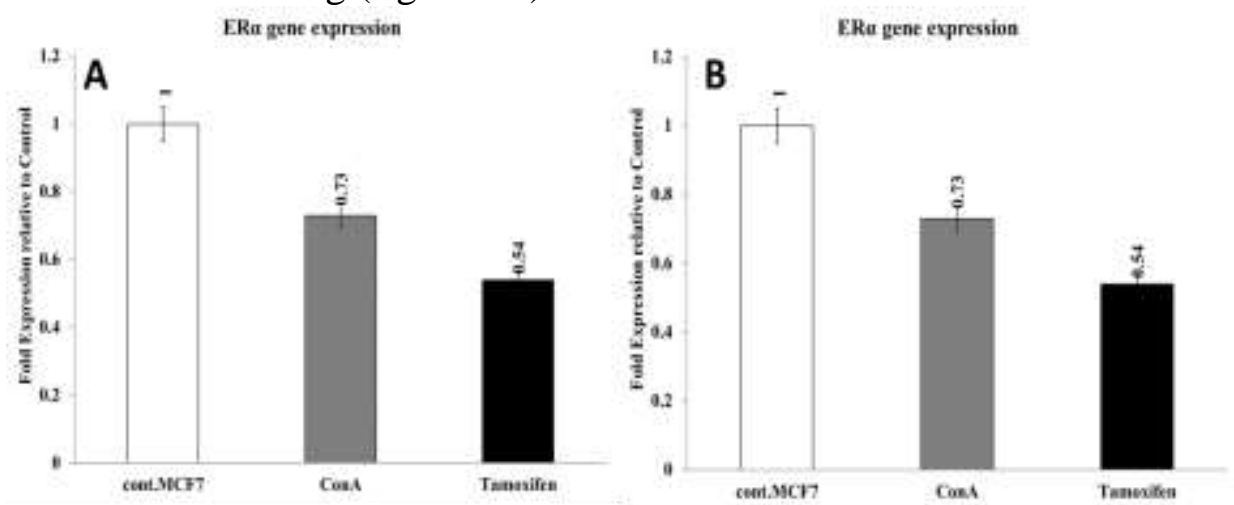

Figure 3: Relative gene expression of ER alpha(A) and the anti-apoptosis gene Bcl-2 (B). Data representative of mean of three independent experiments. 


\section{DISCUSSION}

Concanavalin A (ConA) is a long-studied representative legume lectin that reportedly diversifies human cancer cell death by targeting programmed cell death (PCD) (Tammy et al., 2015). Additionally, ConA reportedly induces leukemic cell death and promoted apoptosis with DNA fragmentation (Zheng et al. 2014). In Zheng et al. 2014 study, ConA induced MCF-7 apoptosis cell death in a dose- and time-dependent manner. The WST-1 assay demonstrated that after $24 \mathrm{~h}$ incubation with $18 \mu \mathrm{g} / \mathrm{mL}$ ConA, the MCF-7 cell inhibitory rate reached nearly $50 \%$, while the ConA IC 50 values detected by the CCK-8 assay were $15 \mu \mathrm{g} / \mathrm{mL}$. In agreement with that study, our data revealed that MCF7 cells when incubated with different concentrations of ConA and Tamoxifen as for 24 $\mathrm{h}$, resulted in a more potent growth inhibitory activity toward MCF-7 cells than Tamoxifen alone as indicated by morphological alterations typical of apoptosis, and growth inhibition activity more prevalent in samples treated with tamoxifen than samples treated with ConA.

In addition, cell growth progression may be another mechanism by which tamoxifen and ConA exert their anti-proliferative effects on MCF-7 cell line. In the current study, MTT reduction assay showed a significant inhibition of cell growth in samples treated with in samples treated with TAM in comparison with that treated with ConA. Additionally, results of the MTT assay indicated that the calculated IC50 of ConA was $7.55 \mathrm{uM}$, and of Tamoxifen was $2.75 \mathrm{uM}$. These results indicated that TAM has a great cytotoxicity effect toward MCF-7 cells than ConA. These results indicated that different mechanisms (apoptosis induction) were induced by Tamoxifen and ConA.

Estrogen receptor- $\alpha(\mathrm{ER} \alpha)$ is a key transcription factor in breast cancer that participates in a variety of different signaling pathways and promotes the expression of the oncogenic protein Bcl-2 protein (Sabbah et al. 1999). In addition, it was reported that down-regulation of ERa accompanied with retardation of progression of the cell cycle, and reduced Bcl-2 expression, frequently leading to apoptosis (Altucci $\boldsymbol{e t}$ al. 1996). In agreement with these data, we found that the inhibition of MCF7 cells growth was accompanied with downregulation of ER $\alpha$ mRNA that treated with conA (0.73 fold), Tamoxifen ( 0.55 fold). In addition, we found a significant decrease in the expression of Bcl-2 in MCF-7 cells treated tamoxifen and that treated with ConA. These data are in line with study by Mohamed et al. (2019) who assessed the antitumor activity of Sal-B against breast cancer cells and compare it to 
that of the chemotherapeutic drug cisplatin. The researchers found that Sal-B significantly reduced the cell viability of MCF-7 cells in vitro in a concentration-and time-dependent manner through a mechanism involves reduction of the oncogenic anti-apoptotic gene $\mathrm{Bcl} 2$. In another study by Luiz et al. (2018), MCF7 cells treated with Halilectin-3H3 at $100 \mu \mathrm{g} / \mathrm{ml}$ for $6 \mathrm{~h}$ showed an over-expression of CASP 3 and CASP 8. Remarkably, after $24 \mathrm{~h}$ there was a decrease in the expression of the anti-apoptotic gene BCL-2 but not in BAX and TP53. Thereby, emphasizing the role of Bcl-2 in inducing MCF7 apoptosis.

In summary, the present study, demonstrated that the lectin ConA was able to induce apoptosis in ER alpha-positive MCF-7 cell line in a comparable fashion as the breast cancer-chemotherapy Tamoxifen and that may be related to the downregulation of the transcription factor ERAlpha and accompanied downregulation of the oncogenic anti-apoptosis gene BCL-2. Finally, our results indicate that ConA exerts anti-tumor actions against human breast carcinoma MCF-7 cells in vitro and confer support for more research to unravel the potentials of using concanavalin-A as complementary treatment of ER+ breast cancer.

\section{REFERENCES}

Altucci, L. ; R. Addeo ; L. Cicatiello ; S. Dauvois and M.G. Parker (1996): 17beta-Estradiol induces cyclin D1 gene transcription, p36D1-p34cdk4 complex activation and p105Rb phosphorylation during mitogenic stimulation of $\mathrm{G}$ (1)-arrested human breast cancer cells. Oncogene., 12: 2315-2324.

Cavada, B.S. ; V.R. Pinto-Junior ; V.J.S. Osterne and K.S. Nascimento (2019): ConA-Like Lectins: High Similarity Proteins as Models to Study Structure/Biological Activities Relationships. Int J Mol Sci., 20(1): 30. doi: 10.3390/ijms20010030.

Faheina-Martins, G.V.; A.L. Silveira ; M.V. Ramos ; L.F. MarquesSantos and D.A.M. Araujo (2011): Influence of Fetal Bovine Serum on Cytotoxic and Genotoxic Effects of Lectins in MCF-7 Cells. J.Biochem Molecular Toxicology., 25(5) Doi 10:1002/Jbt.

Girish, Ch.; Vijayalakshmi, P.; Ramesh Mentham; Chandu Babu Rao and Sreekanth Nama. (2014): International Journal of Pharmacy and Biological Sciences. IJPBS |Volume 4| Issue 2|APR-JUN|.

Lazzeroni, M.; S.Davide; K.Barbara; M.Brandy; L.Oukseub; K. Seema and D. Andrea (2012): Oral low dose and topical tamoxifen for breast cancer prevention: modern approaches for an old drug. Breast Cancer Research, 14:214. 
Lelli, K.M.; M. Slattery and R.S. Mann (2012): Disentangling the many layers of eukaryotic transcriptional regulation. Annu Rev Genet.; 46:43-68.

Luiz G do Nascimento-Neto; Maria G.Cabral; Romulo F. Carneiro; Zelia Silva; Francisco V.S. Arruda; Celso S. Nagano; Alexandra R. Fernandes; Alexandre H. Sampaio; Edson H. Teixeira and Paula A. Videira (2018): Halilectin-3, a Lectin from the Marine Sponge Haliclona caerulea, Induces Apoptosis and Autophagy in Human Breast Cancer MCF7 Cells Through Caspase-9 Pathway and LC3-II Protein Expression. Anticancer Agents Med Chem; 18(4):521-528. doi: 10.2174/1871520617666171114094847.

Marques, G.F.O.; V.J.S. Osterne ; L.M. Almeida ; M.V. Oliveira ; L.A.C. Brizeno ; V.R. Pinto-Junior ; M.Q. Santiago ; A.H.B. Neco ; M.R.L. Mota and L.A.G. Souza (2017): Contribution of the carbohydrate-binding ability of Vatairea guianensis lectin to induce edematogenic activity. Biochimie; 140:58-65. doi: 10.1016/j.biochi.2017.06.008.

Mohamed, A.K. ; A. Rafik; A. Abdulmohsin; A. Mohamed and A. Ahmed (2019): Salvianolic Acid B Slows the Progression of Breast Cancer Cell Growth via Enhancement of Apoptosis and Reduction of Oxidative Stress, Inflammation, and Angiogenesis Int J Mol Sci., 12;20(22):5653. doi: 10.3390/ijms20225653.

Ong, C.T and V.G. Corces (2011): Enhancer functions: new insights into the regulation of tissue-specific gene expression. Nat Rev Genet.; 12:283-293.

Sabbah, M.; D. Courilleau ; J. Mester and G. Redeuilh (1999): Estrogen induction of thecyclin D1 promoter: involvement of a cAMP response-like element. Proceedings of the National Academy of Sciences., 96: 11217-11222.

Spitz, F. and E.E. Furlong (2012): Transcription factors: from enhancer binding to developmental control. Nat Rev Genet. 13:613-626.

Sweeney, E.E.; R.E. Mcdaniel ; P.Y. Maximov ; P. Fan and V. Craig, (2013): Models and Mechanisms of Acquired Antihormone Resistance in Breast Cancer: Significant Clinical Progress despite Limitations. Horm Mol Biol Clin Investig., 9: 143-163.

Tammy, Y.; D. Xiuli ; Charlene Cheuk ; N. Wing and N Tzi Bun (2015): Lectins with potential for anti-cancer therapy. Molecules 26; 20(3):3791-810. doi: 10.3390/molecules20033791.

Zheng, S.H.I.; C.H.E.N. Jie ; L.I. Chun-yang ; A.N. Na ; W.A.N.G. Zi-jie ; Y.A.N.G. Shu-lin ; H.U.A.N.G. Kai-feng and B.A.O. Jin-ku (2014): Antitumor effects of concanavalin A and Sophora favescens lectin in vitro and in vivo. Acta Pharmacologica Sinica; 35: 248-256. 
Egypt. J. of Appl. Sci., 35 (12) 2020

دراسات جزيئية حيويه لعامل نسخ مستقبل الاستروجين في مرض سرطان الثي المعالج باليكتين

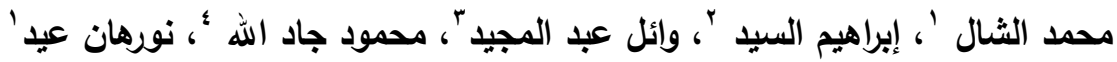

1-قسم البيولوجيا الجزيئية، معهد الهندسة الوراثية والتكنولوجيا الحيوية، جامعة مدينة السادات. r-قسم الكيمياء، كلية العلوم، جامعة كفر الثيخ. r-قسم الوراثة، كلية الزراعة، جامعة بني سويف. ع-ققم المشخصات الجزيئية، معهز الهندسة الوراثية والتكنولوجيا الحيوية، جامعة مدينة السادات.

المقدمة

يعتبر سرطان الثذي من الأورام الخبيثة ويبدأ في خلايا الثدي. والورم الخبيث هو مجموعة من

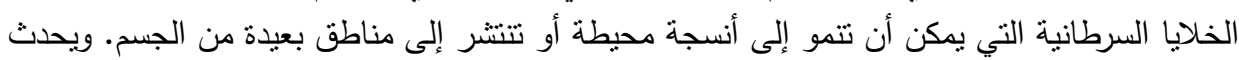

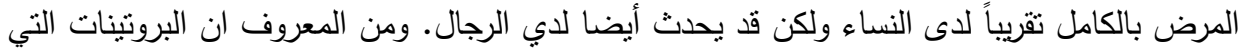

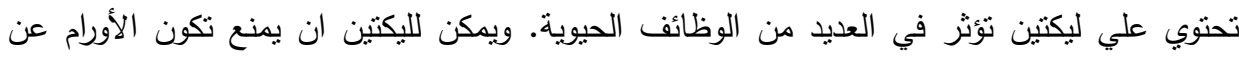
طريق ربط البروتينات الزلالية على غشاء الاغشية السرطانية. الهدف من الاراسة البرونة

تهذف الدراسة الي قياس نشاط الايض الخلوي كمؤشر على قدرة الخلايا على البقاء والانتشار

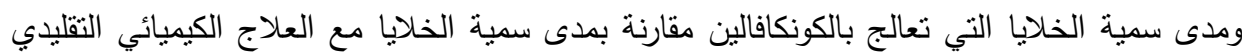
ل السرطان الثدي بعقار التاموكسيفين.

المواد والطرق المستخدمة

تمت الدراسة من خلال تقنيات زراعة الخلايا بواسطة كيماويات خاصة ونتم تقييم مدى سمية

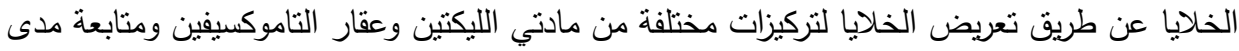

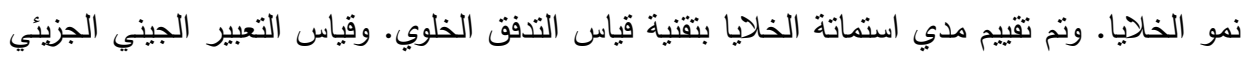

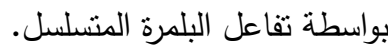
النتائج

أظهرت الدراسة ان استخدام الكونكافالين أدى الي موت واضح للخلايا السرطانية كما أدى أيضا

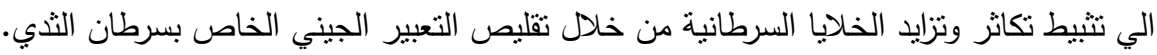

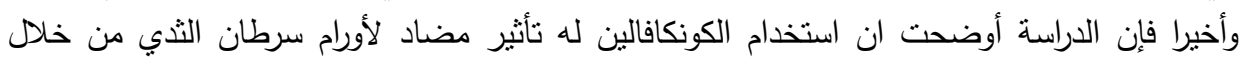
زراعتها خارج الجسم مما يفتح المجال من خلال دراسة استخدام الكونكافالين كمساعد علاجي في علاج الإن

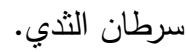

